\title{
Agora se pode fotografar tudo
}

Franklin Alves Dassie

UFF

\section{Resumo}

Este artigo pretende discutir como a experiência fotográfica pode se apresentar como forma de resistência a um consumo compulsivo de imagens na contemporaneidade. Para isso discute, sobretudo, a tomada de posição crítica de Roland Barthes em $A$ câmera clara - em diálogo com outros críticos que pensaram a fotografia e alguns fotógrafos - e imagina um cenário em que as temporalidades que atravessam o gesto de observar as fotografias funcionam como maneira de suspender uma percepção alienante e acrítica.

Palavras-chave: Roland Barthes; fotografia; contemporaneidade; temporalidade.

\begin{abstract}
This article intends to discuss how the photographic experience can present itself as a form of resistance to a compulsive consumption of images in contemporaneity. To do that it discusses, mostly, Roland Barthes positiontaking in "Camera lucida: reflections on photography" - dialoguing with other critics that delved into Photography and some photographers - and conceives a scenario in which the temporalities that pass through the gesture of observing the photographs function as a way to suspend an alienating and uncritical perception.
\end{abstract}

Keywords: Roland Barthes; photography; contemporaneity; temporality. 
1. FRANK, Robert apud SONTAG, Sontag. Sobre fotografia, 2004, p. 203.

2. SONTAG, Sontag. Sobre fotografia, 2004, p. 115.

\section{BENJAMIN, Walter.}

"Pequena historia da fotografia", 2012, p. 111.
Há em "Breve antologia de citações", um dos capítulos de Sobre fotografia de Susan Sontag, uma afirmação, a princípio óbvia, de Robert Frank: "Agora se pode fotografar tudo"1. Em The americans - livro que o consagrou como um dos mais influentes fotógrafos do pós-guerra -, há fotografias de "tudo" mesmo: um funeral em Carolina do Sul, uma loja de doce cheia de crianças em Nova York, um bonde em Nova Orleans, a vista da janela do hotel em Montana, um carro coberto com uma lona na Califórnia, uma vítima de atropelamento numa estrada do Arizona, a vista de uma estrada no Novo México, casais namorando num parque em Michigan, uma cafeteria em Indianópolis, uma loja de departamento em Nebraska, uma família dando um passeio de carro em Detroit, um banheiro masculino no Tennessee, um jovem ascensorista num elevador em Miami Beach, entre tantas outras coisas. Foram tiradas, aproximadamente, vinte e oito mil fotografias ao longo da viagem que Robert Frank fez com a família de carro pelos Estados Unidos da América em meados da década de cinquenta, mas só oitenta e três foram publicadas em The americans.

"Agora se pode fotografar tudo" é uma boa entrada para The americans, mas também é possível pensar essa afirmação como uma maneira de compreender o procedimento estético de Robert Frank, sobretudo no entendimento da fotografia não mais como uma prática que revela "um modo genuinamente novo de ver (preciso, inteligente e até científico)" solicitado por modernistas como Cartier-Bresson. Esse projeto - da fotografia como experiência capaz de desvelar "uma nova visão do mundo" - foi contestado pela geração posterior de fotógrafos. E Frank, segundo Susan Sontag, foi um daqueles que "almejavam para a câmera um olhar que não seja penetrante, mas sim democrático, que não reivindique estabelecer novos padrões de visão"2. A ideia de um olhar democrático é a possibilidade de crítica de uma suposição - de alguma forma romantizada - do fotógrafo como artista e, portanto, de uma noção de beleza que seria revelada exclusivamente pela câmera-olho do fotógrafo-artista. Décadas antes, Walter Benjamin, em "Pequena história da fotografia", já assinalava o interesse na estética da "fotografia como arte" ao invés do interesse - mais evidente e produtivo da compreensão da "arte como fotografia". Daí ele destacar a importância da democratização por meio da reprodutibilidade, que foi colocada de lado em favor da "construção mais ou menos artística de uma fotografia"3.

Quase sessenta anos depois da publicação de The americans - onde Frank, realmente, fotografou tudo ou quase tudo - a questão da democratização das imagens é recolocada a partir de uma perspectiva outra, a confluência do consumo, compulsão e banalização da experiência fotográfica. Em Imagem da fotografia, 
Bernardo Pinto de Almeida afirma que não é possível ter "uma imagem da fotografia". A vontade de definição esbarra em um duplo problema, uma vez que "a fotografia é o lugar de todas as imagens" e "todas as imagens são, também, lugares da fotografia". Duplo problema este que se desdobra: "a imagem fotográfica alojou-se por toda a parte, invadiu o mundo, reduzindo-o à espessura mínima de uma prova, de uma reprodução"4 . A fotografia como prova e como reprodução diz respeito, por um lado, à sua relação direta com o real: "uma foto não é apenas uma imagem (como uma pintura é uma imagem), uma interpretação do real", uma foto, diz Sontag, "é também um vestígio, algo diretamente decalcado do real" ${ }^{5}$. Por outro lado, essa prova/reprodução vestigial é "espessura mínima”, esvaziada de sentidos por uma produção e consumo compulsivos de imagens fotográficas, alojadas "por toda a parte”, já que invadiram o mundo. Isso se relaciona com a capacidade da fotografia ser, de múltiplas formas, "uma aquisição", segundo Sontag. Enfim, de compreender a fotografia como possibilidade de aquisição de algo, possibilidade esta atravessada pelas ideias de quantidade e propriedade.

Isso acontece de três maneiras. Em primeiro lugar, de forma simples, substituo a ausência de "uma pessoa ou coisa querida" por uma imagem, "uma posse que dá às fotos um pouco do caráter próprio dos objetos únicos". Estabeleço, em segundo lugar, através das fotografias, uma posição de consumidor com os eventos, com aqueles que fazem parte da minha experiência, mas também com aqueles que não fazem, daí "uma distinção de tipos de experiência que tal consumo de efeito viciante vem turvar". Por fim, "mediante máquinas que criam imagens e duplicam imagens", posso assim "adquirir algo como informação (e não como experiência)", assim um conhecimento que chega dissociado da última e que se torna "parte de um sistema de informação", se adaptando a "esquemas de classificação e de armazenagem" e, portanto, a sistemas burocráticos e ideológicos de controle ${ }^{6}$. Consumo e compulso imagens, produzo-as para que outros as consumam e as compulsem, entro em uma lógica incessante - "Agora se pode fotografar tudo" ganha outro sentido: "A razão final para a necessidade de fotografar tudo repousa na própria lógica do consumo em si. Consumir significa queimar, esgotar - e, portanto, ter de se reabastecer"'. Preciso de mais imagens: consumo e compulso mais imagens, produzo-as para que outros as consumam e as compulsem também de modo incessante. Banalizo a prática democrática da experiência fotográfica, não solicito mais um olhar "genuinamente novo" - "uma nova visão do mundo" -, mas neutralizo a capacidade crítica antes inscrita aí e transformo o mundo em uma experiência tautológica.

Para Almeida, ainda em Imagem da fotografia, tal estado de coisas pode ser enfrentado, paradoxalmente, pela fotografia
4. ALMEIDA, Bernardo Pinto. Imagem da fotografia, 2014, p. 72.

5. SONTAG, Susan. Sobre fotografia, 2004, p. 170.

6. Ibidem, p. 172.

7. Ibidem, p. 195. 
8. ALMEIDA, Bernardo Pinto. Imagem da fotografia, 2014, p. 72.

9. SONTAG, Susan. Sobre fotografia, 2004, p. 180.

10. ALMEIDA, Bernardo Pinto. Imagem da fotografia, 2014, p. 72-3.

11. Ibidem, p. $72-73$, grifos meus.

12. Ibidem, p. 73.

13. Ibidem, p. 74 mesma, é ela que pode restituir a capacidade crítica da imagem, desconstruindo a cultura da imagem: "Caberá à fotografia fazer ruir aquilo mesmo que a fotografia erigiu enquanto modo de aproximação ao real, enquanto veículo de mediatização e de reificação do mundo" ". Modo de aproximação do real que, de acordo com Sontag, nada mais é do que uma forma de "criar distância": "Possuir o mundo na forma de imagens é, precisamente, reexperimentar a irrealidade e o caráter distante do real"'. Caberá, então, à fotografia reaproximar-nos do real, afrontar "uma ordem que, senão um sistema, que é simultaneamente técnica e ideológica, sem que seja possível destrinçar o que, no seu interior e no seu modo de se agenciar, é parte de uma e da outra". A fotografia se apresenta como uma prática que intentará "voltar a dar à imagem um lugar que a não feche numa situação compulsiva" e que "subtraia à imagem toda essa carga de mistificação e de abuso que a sua utilização indiscriminada pelos mass media suscitou" ${ }^{\prime 10}$. A tarefa é exorbitante para a fotografia: o enfrentamento de uma lógica compulsiva de consumo, uma atitude de resistência à cultura espetacular da imagem. Embora um tanto messiânica - ele fala do surgimento de "profetas dessa revolta contra a redução de tudo ao estatuto da imagem", no interior mesmo da história da fotografia -, a perspectiva de Almeida é interessante. Isso porque não há um ataque contra as imagens, nem uma solicitação apocalíptica pelo seu fim, mas uma "subversão da imagem pela própria imagem". Para o crítico, há um nome, de menção "indomável”, capaz de "alertar para essa subterrânea desprogramação do olhar", o de Robert Frank ${ }^{11}$.

Por um lado, a escolha de Frank é justificada pela sua capacidade de resistir a "um olhar acadêmico", purista, mostrando em sua prática fotográfica o que é "da ordem da impureza e assumindo as consequências desse gesto". Por outro, e ao mesmo tempo, investe a fotografia de uma "outra função", capaz de libertar "o olhar de quem as contempla, colocando-o face a uma responsabilidade que faz coincidir ética e estética"12. A retórica messiânica - quando Almeida pensa a fotografia como resistência à cultura da imagem e quando escolhe o nome de Robert Frank - sugere, em certo sentido, que ele seria o fotógrafo-profeta capaz de libertar o olhar para "uma nova visão do mundo", mas uma nova visão figurada a partir da impureza. Entretanto, o procedimento de Frank, ao assumir a impureza, é a crítica a uma série de convenções "acadêmicas" - sua prática estética fotográfica torna possível, assim, uma abertura ao outro, sendo ética por isso. Marginal à visibilidade das imagens de "espessura mínima", sua experiência coloca em cena um olhar "oblíquo, descentrado, excêntrico (desfocado, às vezes) que restituiu a quem as olha uma liberdade de ver e de escolher no interior de cada imagem um fio condutor para o seu próprio olhar" ${ }^{\prime 13}$. 
A abertura é a condição para aquele que vê uma fotografia participar do processo, não ser mais um mero espectador, mas sim alguém alerta para estabelecidas pedagogias do olhar, alguém que, diante de uma imagem, se coloca como um observador ${ }^{14}$.

A experiência do olhar "volta a ser acto, a ter a dimensão de uma aventura", a imagem fotográfica pode escapar, assim, da previsibilidade da informação e da lógica do consumo que se esgota em si mesma - consumo e compulso a mesma fotografia - e solicita mais e mais imagens. Como acto e aventura, a prática fotográfica pode voltar a surpreender quando, "estetizado pelas imagens, consumido pelas imagens", quase "nada parece poder surpreender-nos e, muito menos, comover-nos"15 - é ver como se estivesse vendo pela primeira vez, como se fosse "indomável" de novo diante da primeira fotografia. A liberdade não se apresenta, nesse sentido, como a "liberdade de consumir uma pluralidade de imagens", que é "equiparada a liberdade em si" ${ }^{16}$, mas como a de "se furtar a tudo quanto na imagem se torna espetacular" ${ }^{17}$. A fotografia de Robert Frank - ou de um Garry Winogrand, pois há outros profetas marginais - sendo democrática, assumindo a impureza, me permite entrar na cena de um olhar/uma prática à margem da cultura do espetáculo (e do consumo), a me aventurar pelas imagens - escolho um fio condutor entre tantos outros - e, sobretudo, a me alertar para uma compreensão crítica da fotografia e da atribuição de outros sentidos e experiências ao ato de ver, atravessado assim pela surpresa, pelo tempo e pela minha própria morte.

A atribuição de outros sentidos e experiências ao ato de ver como possibilidade de figuração do olhar à margem da cultura espetacular - o olhar sendo acto e aventura, indomável e até mesmo selvagem - e a desprogramação aí solicitada remetem à escolha da prática fotográfica de Robert Frank como resistência à imagem através da própria imagem. Ele representaria, assim, uma tomada de posição crítica em relação a um cenário em que se produzem e consomem imagens de maneira compulsiva e a experiência do olhar é atravessada por previsibilidades. Mas a imagem de Frank - é possível falar em imagem como construção crítica que se dá a partir/em torno de uma figura - é revelada por meio de outra figura, a de Roland Barthes. A leitura de Frank em Imagem da fotografia, e outras leituras no mesmo livro, pontuada pela ideia de "subterrânea desprogramação do olhar", é um questionamento do lugar-comum - do clichê - da fotografia, do uso cultural das imagens, e a solicitação de um afeto

\section{Penso no termo}

"observador" a partir do uso que Jonathan Crary faz dele em Técnicas do observador: Visão e modernidade no século XIX.

Diz Crary: "A maior parte dos dicionários faz pouca distinção entre as palavras "observador" e "espectador", e o uso comum em geral as converte em sinônimos. Escolhi o termo observador sobretudo por suas ressonâncias etimológicas. Diferente de spectare, raiz latina de "espectador", a raiz de "observar" não significa literalmente "olhar para". Espectador também carrega conotações específicas, especialmente, no contexto da cultura do século XIX, que prefiro evitar - concretamente, aquele que assiste passivamente a um espetáculo, como em uma galeria de arte ou em um teatro. Em um sentido mais pertinente ao meu estudo, observar significa "conformar as próprias ações, obedecer a, como quando se observam regras, códigos, regulamentos e práticas. Obviamente, um observador é aquele que vê. Mas o mais importante é que é aquele que vê em um determinado conjunto de possibilidades, estando inscrito em um sistema de convenções e restrições". In: CRARY, Jonathan. Técnicas do observador, 2012, p. 15.

15. ALMEIDA, Bernardo Pinto. Imagem da fotografia, 2014, p. 74.

16. SONTAG, Susan. Sobre fotografia, 2004, p. 195.

17. ALMEIDA, Bernardo Pinto. Imagem da fotografia, 2014, p. 75. 
18. BARTHES, Roland. $A$ câmara clara, 2015, p. 14-15.

19. POE, Edgar Allan. "O daguerreotipo”, 2013, p. 56.

20. SONTAG, Susan. Sobre fotografia, 2004, p.16, grifos meus.

21. BARTHES, Roland. A câmara clara, 2015, p. 16. pessoal em sua observação. Enfim, a imagem de Robert Frank figuraria em $A$ câmera clara.

A câmera clara é escrita por um desejo de "saber a qualquer preço" o que é a fotografia - que aspecto a distingue da "comunidade das imagens" - e de uma primeira constatação óbvia e desconcertante: a fotografia "repete mecanicamente o que nunca mais poderá repetir-se existencialmente". Reduzindo, diz Barthes, "sempre o corpus de que tenho necessidade ao corpo que vejo", a fotografia é o "Particular absoluto, a Contingência soberana", ela é "o Tal (tal foto, e não a Foto)". Ela "jamais se distingue de seu referente (do que ela representa), ou pelo menos não se distingue dele de imediato ou para todo mundo", uma vez que ela não é, como as outras imagens, um objeto simulado - há a "teimosia do Referente em estar sempre presente"18. Nada de novo, obviedade que é repetida desde o surgimento da fotografia. Edgar Allan Poe, quase um século e meio antes de Barthes, já ressaltava essa "teimosia" na invenção de Daguerre, ao afirmar que "a chapa daguerreotipada é infinitamente (utilizamos o termo de modo intencional), é infinitamente mais precisa na sua representação do que qualquer pintura efectuada por mão humanas" ${ }^{19}$. Sontag, ao comentar um uso burocrático das fotos, lembra que elas "fornecem um testemunho" e completa, afirmando que uma "foto equivale a uma prova incontestável de que determinada coisa aconteceu" ${ }^{20}$ ".

Há inúmeros outros exemplos e há minha prática como sujeito-observador: vejo um carro coberto com uma lona na frente de um lugar - que se parece com um escritório, pois há uma placa na porta - e duas palmeiras, fazendo sombra na parede desse lugar. A foto está em The americans, se chama Covered car e foi tirada em Long Beach, Califórnia, em 1955, por Robert Frank. Mas ela é o "Particular absoluto", ela é isso: um carro coberto com uma lona na frente de um lugar - que se parece com um escritório, pois há uma placa na porta - e duas palmeiras, fazendo sombra na parede desse lugar. Não há dúvida, vejo tal foto, $t a l$ referente, e não outra coisa.

Essa "aderência singular" do referente dificulta a acomodação da vista à fotografia, daí a "dificuldade" de pensá-la: ou se precisa "acomodar a vista muito perto" no caso dos estudos técnicos ou "acomodar a vista muito longe" no caso dos estudos históricos ou sociológicos. Diante de certas fotos, Barthes "só via o referente, o objeto desejado, o corpo prezado" e isso - "a teimosia do Referente" - o levava a negar a compreensão sociológica e a se desejar "selvagem, sem cultura ${ }^{21}$ ". Covered car seria, assim, uma imagem capaz de instigar a curiosidade de quem a vê, como em um jogo de esconder, atravessado por um desejo, quase erótico, de desvelar aquilo que está "vestido" pela lona. Covered car não seria, em um livro chamado The americans, a imagem de um cuidado excessivo - perto do cuidado 
maternal (cobri-lo como se cobre um filho ao colocá-lo para dormir) - e sugestivo que os americanos têm com o carro. Ao propor a "ideia bizarra" de uma "ciência nova por objeto", se colocando ele próprio "como medida do 'saber' fotográfico" 22 , Barthes propõe um deslocamento do lugar-comum cultural que é pensar a fotografia tecnicamente, como documento social e histórico e como espetáculo. Deslocar-se desse lugar pode ser "transportar-se para onde não se é esperado, ou ainda e mais radicalmente, abjurar o que se escreveu" 23 quando qualquer estratégia de poder o coloniza. É uma espécie de "prática do abalo", um procedimento crítico - aprendido em Brecht - "que abre uma crise: que rasga, que fissura a camada envolvente, fende a crosta das linguagens". Muito mais que uma "semiologia", Barthes vê esse procedimento como uma "sismologia": o abalo é "repetido quando necessário, mas jamais instalado" 24 . A câmera clara se apresenta então como uma crise pessoal - uma fenda na linguagem crítica - capaz de sugerir outros modos de percepção da experiência fotográfica. Como fenda, abertura crítica, permite de forma generosa a presença do outro a se colocar aí como observador, daí o transporte para um lugar inesperado e a contribuição que jamais se instala.

A câmara clara é a "vontade" de argumentação dos "humores" - a experiência perceptiva - de Barthes em relação à fotografia e isso, segundo ele, não para preencher com sua "individualidade a cena do texto", mas "para oferecê-la, estendê-la, essa individualidade, a uma ciência do sujeito", sem nome ainda, que alcance "uma generalidade que não me reduza nem me esmague" 25. A leitura solicita a "atração" que ele sente por algumas fotografias. Atração que não é "fascinação" nem "interesse", mas aquilo que lhe dá "o estalo" - uma atração que "era aventura". Diz Barthes: "Tal foto me advém, tal outra não". É o "princípio de aventura" que dá existência à fotografia, que a faz existir: "uma animação" 26 . Em um cenário em que consumo e compulso imagens, de modo indiferenciado, uma fotografia que se apresente como aventura solicita uma percepção acidental, inesperada, ou até mesmo "indomável”, que coloca a minha prática de ver em risco, em perigo - a fotografia me anima, pois me dá a "liberdade de ver e de escolher no interior de cada imagem um fio condutor" ${ }^{27}$.

A partir daí Barthes nomeia dois elementos que fundam o seu interesse - a sua animação - por certas fotografias. O primeiro deles percebido com "bastante familiaridade em função de meu saber, de minha cultura”, é um interesse que percorre um campo bem vasto, um "interesse geral, às vezes emocionado, mas cuja emoção passa pelo revezamento judicioso de uma cultura moral e política". A esse interesse, que é experimentado com "um afeto médio, quase como um amestramento"28, Barthes chama de studium. Participo culturalmente da arquitetura,
22. Ibidem, p. 17.

23. Idem. Aula, 1995, p. 27.

24. Idem. "Brecht e o discurso: contribuição para o estudo da

25. Idem. A câmara clara, 2015, p. 24.

26. Ibidem, p. 24-25.

27. ALMEIDA, Bernardo Pinto. Imagem da fotografia, 2014, p. 74.

28. BARTHES, Roland. $A$

câmara clara, 2015, p. 27. 
29. SMITH, Patti. Só garotos, 2010.

30. BARTHES, Roland. $A$ câmara clara, 2015, p. 31.

31. Ibidem, p. 29.

32. Ibidem, p. 46.

33. Diz Barthes: "Com muita frequência, o punctum é um "detalhe", ou seja, um objeto parcial. Assim, dar exemplos de punctum é, de certo modo, entregar-me". Ibidem, p. 42. da vida das pessoas, das ações e dos objetos e essa participação é um "meio desejo, um meio querer" - próxima de uma experiência etnológica - polido e geral. É assim que vejo a Nova York de Walker Evans das primeiras décadas do século passado: os arranha-céus, a moda, os cenários, entre outras coisas. É assim que acompanho um pouco da vida de Patti Smith nas fotografias que Judy Linn fez dela entre 1969 e 1976, seu modo de vestir, seu convívio com Robert Mapplethorpe - essas imagens, de certa forma, ilustram a minha leitura de Só garotos $^{29}$, espécie de biografia de Nova York das décadas de 60 e 70 . Pelo studium, passeio por The americans como um retrato da cultura norte-americana da década de cinquenta: aprendo, assim, alguma coisa sobre ela a partir do olhar de Robert Frank. A percepção cultural - a do studium - é um afeto que fornece uma "coleção de objetos parciais" e que pode ressaltar "certo fetichismo: pois há um "eu" que gosta do saber, que sente a seu respeito como que um gosto amoroso" 30 . A fotografia é então um documento, uma prática do olhar que me permite o acesso a inúmeros saberes.

Há um segundo elemento que "vem quebrar (ou escandir) o studium", um elemento que, segundo Barthes, "não sou eu que vou buscá-lo", ao contrário da percepção cultural do studium, "é ele que parte da cena, como uma flecha, e vem me transpassar". Esse elemento é uma "ferida", "picada", "marca feita por um instrumento pontudo", "pequeno corte", capaz de colocar em risco, mas nunca destruir, o olhar generalizado da cultura, é uma suspensão momentânea dela - no sentido de me fazer "selvagem" outra vez - que Barthes chama de punctum. Ele, numa imagem, "é esse acaso que, nela, me punge (mas também me mortifica, me fere)"31. Pode-se dizer que ele se apresenta como figuração marginal da visibilidade. Esse detalhe suspende certo fetichismo do saber: daí a Nova York de Evans, a vida de Patti Smith pelas lentes de Linn e os americanos de Frank são encarados de outra maneira: um detalhe arquitetônico, um serrote pendurado na parede, o olhar de uma jovem partem da cena e a cultura fica à margem: o punctum é "uma fulguração". "Pela marca de alguma coisa, a foto não é mais qualquer" ${ }^{32}$ - alguma coisa que não está codificada, como o studium, que não tem nome e por isso pode ferir. Essa alguma coisa pode, realmente, ser qualquer coisa: sapatos de presilha, os maus dentes de um garoto, os braços cruzados de um marinheiro, a vontade, inexplicável, de viver em algum lugar, para lembrar exemplos de punctum confes$\operatorname{sados}^{33}$ por Barthes.

Diante de um cenário em que as imagens são produzidas e consumidas de forma imediata, o punctum, como "força de expansão", é uma afronta crítica, enfim, é a chance de problematização de um uso compulsivo da técnica. Pois se hoje as imagens fotográficas são "infinitamente" mais precisas do que em seu começo, é possível pensar - como fez Benjamin - que 
"a técnica mais exata pode dar às suas criações um valor mágico", valor este que solicita no "observador" a "necessidade irresistível de procurar nessa imagem a pequena centelha do acaso, do aqui e agora, com a qual a realidade chamuscou a imagem". Fulguração ou centelha, esse detalhe e a percepção aí envolvida "substitui um espaço preenchido pela ação consciente do homem por um espaço em que ele preenche agindo inconscientemente". Através de seus recursos, desse olhar técnico, a fotografia "revela esse inconsciente ótico" 34 . A imagem ganha assim uma potência que é, com frequência, neutralizada pela repetição exaustiva da mesma fotografia - um clichê - que o par consumo/compulsão instiga. Procurar aquilo que a realidade revelou na fotografia - se dispor a outro tipo de experiência perceptiva - é um gesto crítico que $A$ câmara clara apresenta em sua tentativa de figuração de uma "ciência do sujeito". Pelo punctum, com sua força dilacerante de surpresa, a imagem passa a ser percebida dentro de outra temporalidade, menos alienante e, portanto, muito mais histórica.

John Berger, em "Compreender uma fotografia", afirma que o "verdadeiro conteúdo de uma fotografia é invisível, porque deriva de um jogo, não com a forma, mas com o tempo". Para ele, a fotografia é uma escolha entre tantas outras, mas, sobretudo, uma escolha no tempo - fotografa-se uma coisa, ou uma pessoa, em um momento tal. Assim, toma-se consciência da ausência e presença que atravessam uma fotografia - ela, "ao registrar o que foi visto, refere-se sempre, e pela sua própria natureza, ao que não é visto". Isso acontece por conta do seu jogo com o tempo: "Isola, preserva e apresenta um momento extraído de um contínuo". É isso que confere a ela sua particularidade: "O que mostra evoca o que não se mostra" 35 . A relação temporal daí resultante é discutida por Barthes a partir da noção cinematográfica do "campo cego". Ele lembra, em diálogo com André Bazin, que a tela no cinema "não é um enquadramento, mas um esconderijo" - "o personagem que sai dela continua a viver". Um momento isolado, preservado e apresentado de um contínuo pode dar à fotografia um caráter apenas de imobilidade: os personagens que nela são representadas não se movimentam e, sobretudo, "não saem: estão anestesiados, fincados, como borboletas" ${ }^{36}$. Não sair da foto sugere que não há animação na imagem, não há a criação do campo cego. Isso pode acontecer quando o saber etnológico do studium se transforma, por um desejo de imobilização, num saber entomológico, que finca as borboletas. Pode acontecer também quando a repetição da mesma fotografia espetacular não deixa nenhum espaço de animação por conta de sua redundância informativa. Não há, então, punctum na fotografia - os personagens não saem "fantasmaticamente" dela, que assim fica desprovida de um campo cego.

Quando Berger afirma que aquilo que uma imagem fotográfica mostra acaba evocando "o que não se mostra" e quando
34. BENJAMIN, Walter.

"Pequena história da fotografia", 2012, p. 100-1.

35. BERGER, John.

"Compreender uma fotografia", 2013, p. 319.

36. BARTHES, Roland. $A$ câmara clara, 2015, p. 53. 
37. Ibidem, p. 53.

38. Ibidem, p. 67-8.

39. Ibidem, p. 71.

40. KEROUAC, Jack.

"Introduction", 2008, s/p.

41. BARTHES, Roland. A

câmara clara, 2015, p. 72.
Barthes solicita a noção de campo cego para pensar a animação daquela, estão ambos sugerindo que uma fotografia pode levar "o espectador para fora de seu enquadramento" e é dessa maneira que "essa foto me anima e eu a animo", enfim, que o "punctum é, portanto, uma espécie de extracampo sutil, como se a imagem lançasse o desejo para além daquilo que ela dá a ver" ${ }^{37}$. Ausência e presença, a fotografia abre para aquilo que ela não mostra. Isso se desdobra, mas é preciso retornar ao aspecto mais óbvio dessa experiência: "jamais posso negar que a coisa esteve lâ". Em carne e osso, a coisa esteve lá, "necessariamente real” - diante da câmera, em um tempo específico, na "dupla posição conjunta: de realidade e de passado". A essência da fotografia, seu noema, é: "Isso-foi"38.

Diante de uma fotografia de Robert Frank tirada em Miami, chamada Elevator, vejo um elevador de porta aberta, uma senhora de casaco de pele já fora dele, uma jovem ascensorista de olhar perdido e a sombra de um senhor, a coisa esteve lá, dessa forma. Ela, a imagem, é um "vestígio" desse dia, ou melhor, do momento em que Frank levantou sua Leica e fez a foto. Não rememoro o passado, mas atesto a presença de um momento: isso que vejo existiu, "o que eu vejo não é uma lembrança, uma imaginação, uma reconstituição", diz Barthes, "mas o real no estado passado: a um só tempo o passado e o real" 39 . A presença "necessariamente real" da jovem ascensorista, entretanto, evoca o que não mostra, lança meu desejo para além daquilo que está revelado na fotografia. Esse desejo - uma espécie de curiosidade - fez Jack Kerouac, na introdução de The americans, perguntar: "That little lonely elevator girl looking up sighing in an elevator full of blurred demons, what's her name \& address?" ${ }^{40}$. E fez Barthes, diante de uma fotografia que André Kertész tirou de um estudante em 1931, perguntar se ele vive ainda hoje, como vive, onde vive e completar: "Que romance!". A percepção como gesto romanesco - imaginar uma história a partir de uma imagem - sugere, como disse Berger, que é invisível o "verdadeiro conteúdo" das imagens fotográficas. Uma série de perguntas que constituem uma "metafísica 'boba' ou simples", "provavelmente a verdadeira metafísica", assim explicada por Barthes:

Sou o ponto de referência de qualquer fotografia, e é nisso que ela me induz a me espantar, dirigindo-me a pergunta fundamental: por que será que vivo aqui e agora? Certamente, mais que outra arte, a Fotografia coloca uma presença imediata no mundo - uma copresença; mas essa presença não é apenas de ordem política ("participar dos acontecimentos contemporâneos pela imagem”), ela é também de ordem metafísica. ${ }^{41}$

Ao me colocar como "ponto de referência" de todas as fotografias e me espantar com essa "metafísica boba", fazendo 
uma série de perguntas sobre os personagens que figuram naquelas (será que vivem ainda?), sou consciente da minha presença no mundo e, portanto, do meu desaparecimento futuro desse mesmo mundo: no extremo da morte do outro, "está inscrita minha própria morte" ${ }^{\text {" }}$. Sontag, em Sobre fotografia, lembra que "Tirar uma foto é participar da mortalidade, da vulnerabilidade e da mutabilidade de outra pessoa (ou coisa)". E continua, afirmando que "por cortar uma fatia desse momento e congelá-la, toda foto testemunha a dissolução implacável do tempo"43. Participar da mortalidade de outra pessoa é confirmar a minha morte futura: aquele momento congelado, seja ele qual for, sai da fotografia e me punge. Para Barthes, a proximidade da experiência fotográfica com a morte talvez tenha relação com a "crise da morte" ${ }^{44}$, que se manifesta na segunda metade do século dezenove. Há, nesse sentido, um "vínculo antropológico" da morte com a fotografia: "Pois é preciso que a Morte, em uma sociedade, esteja em algum lugar; se não está mais (ou está menos) no religioso, deve estar em outra parte". A prática fotográfica "corresponderia talvez à intrusão, em nossa sociedade moderna, de uma Morte assimbólica, fora da religião, fora do ritual, espécie de brusco mergulho na Morte literal" ${ }^{45}$. Entre a pose do outro e a minha posse, ou a forma como percebo o outro, a "dissolução implacável do tempo" - o punctum anima a imagem e me mortifica. Em uma sociedade que continua evitando a relação com a morte - e a fotografia, nesse cenário, figuraria como onipresença narcísica da vida - pensá-la como parte da imagem é um escândalo, uma obscenidade inclusive - a metafísica "boba", solicitada pelo punctum, torna a fotografia uma experiência louca, e alucinada, da imagem: ausência e presença, passado e realidade, vida e morte.

A fotografia, assim, pode oferecer resistência ao desejo que a sociedade tem de torná-la sensata. Desejo este que se manifesta através de um movimento de "generalizá-la, gregarizá-la, banalizá-la, a ponto de não haver mais diante dela nenhuma outra imagem em relação à qual" ela, segundo Barthes, "possa se marcar, afirmar sua especialidade, seu escândalo, sua loucura". A afirmação de Robert Frank - "Agora se pode fotografar tudo" - ganha um sentido banal e que sinaliza uma transformação de tudo em imagem, e "generalizada, ela desrealiza completamente o mundo humano dos conflitos e dos desejos, sob o pretexto de ilustrá-lo" ${ }^{46}$. Como diz Sontag: "a realidade passou cada vez mais a se parecer com aquilo que as câmeras nos mostram"47. Parece, nessa tentativa de tornar a fotografia uma experiência sensata, uma vontade de evitar, sobretudo, as surpresas que os conflitos e desejos solicitam - fotografo tudo em uma espécie de relação turística. Inseguro, a câmera me faz acreditar que estabeleço uma relação de posse com os espaços - e de consumo com a realidade. A câmara clara é a possibilidade
42. Ibidem, p. 79.

43. SONTAG, Susan. Sobre fotografia, 2004, p. 26.

44. Em "O narrador", Benjamin já havia comentado essa "crise", ao afirmar que "No decorrer dos últimos séculos, pode-se observar que a ideia da morte vem perdendo, na consciência coletiva, sua onipresença e sua força de evocação. Esse processo acelera-se em suas últimas etapas. Durante o século XIX, a sociedade burguesa produziu, com as medidas higiênicas e sociais privadas e públicas, um efeito colateral que inconscientemente talvez tivesse sido seu objetivo principal: permitir aos homens evitarem o espetáculo da morte". BENJAMIN, Walter. "O narrador”, 2012, p. 223.

45. BARTHES, Roland. $A$ câmara clara, 2015, p. 79.

46. Ibidem, p. 98.

47. SONTAG, Susan. Sobre fotografia, 2004, p. 177. 
48. BARTHES, Roland. $A$ câmara clara, 2015, p. 99.
49. Ibidem, p. 17

50. Ibidem, p. 34.

51. SONTAG, Susan. Sobre fotografia, 2004, p. 19.

52. Ibidem, p. 15.

53. BARROS, Manoel de.

Ensaios fotográficos, 2013, p. 9-10. crítica de se esquivar de uma ordem, técnica e ideológica, que mistifica a imagem ou em uma situação compulsiva ou em uma situação irreal. "Cabe a mim escolher", como diz Barthes ao fim do livro, "submeter seu espetáculo ao código civilizado das ilusões perfeitas ou afrontar nela o despertar da intratável realidade" ${ }^{48}$. Entre o "fotografar tudo" da compulsão ou o "fotografar tudo" da solicitação democrática da experiência do olhar, é a fotografia mesma que figura uma tomada de posição, é ela, em sua alucinação, que me revela uma escolha.

Há um livro de Manoel de Barros chamado Ensaios fotográficos. Ele é dividido em duas partes. A primeira tem o mesmo título do livro e uma epígrafe de Jorge Luis Borges: "Imagens não passam de incontinências do visual". Imagina-se que "Ensaios fotográficos" mostre a prática do operator - como Barthes chama o fotógrafo ${ }^{49}$ - em ação, em seu "gesto essencial", o de "surpreender alguma coisa ou alguém (pelo pequeno orifício da câmara)" "50 Já a segunda parte se chama "Álbum de família" e tem uma epígrafe de Clarice Lispector: "Eu te invento, ó realidade". Imagina-se, nessa parte, que há uma série de instantâneos que sugerem a fotografia como "um rito social", como diz Sontag: "As câmeras acompanham a vida da família"51. E não só isso, mas outro aspecto a atravessa: a noção de organização das imagens em forma de livro. Outra vez Sontag: "Fotos, que enfeixam o mundo, parecem solicitar que as enfeixemos também" ${ }^{2}$. Não há como ser mais explícita a relação desse livro com a experiência fotográfica - uma série de poemas - fotografias - nos ensaios do poeta-operator e uma forma de inventar a realidade - mesmo que familiar - através da organização do álbum. Ensaios fotográficos abre com um poema chamado "O fotógrafo" "53:

Difícil fotografar o silêncio.

Entretanto tentei. Eu conto:

Madrugada a minha aldeia estava morta.

Não se ouvia um barulho, ninguém passava entre as casas.

Eu estava saindo de uma festa.

Eram quase quatro da manhã.

Ia o Silêncio pela rua carregando um bêbado.

Preparei minha máquina.

O silêncio era um carregador?

Estava carregando o bêbado.

Fotografei esse carregador.

Tive outras visões naquela madrugada.

Preparei minha máquina de novo. 
Tinha um perfume de jasmim no beiral de um sobrado.

Fotografei o perfume.

Vi uma lesma pregada na existência mais do que na pedra.

Fotografei a existência dela.

Vi ainda um azul-perdão no olho de um mendigo.

Fotografei o perdão.

Olhei uma paisagem velha a desabar sobre uma casa.

Fotografei o sobre.

Foi difícil fotografar o sobre.

Por fim eu enxerguei a Nuvem de calça.

Representou para mim que ela andava na aldeia de braços dados com Maiakovski - seu criador.

Fotografei a Nuvem de calça e o poeta.

Ninguém outro poeta no mundo faria uma roupa mais justa para cobrir a sua noiva.

A foto saiu legal.

É possível imaginar esse poema como um elogio à destreza do operator. Isso pela repetição de locuções verbais - "Difícil fotografar" e "Foi difícil fotografar" - que sugerem ações complicadas quanto aos objetos, seres ou situações fotografadas, todos surpreendentes. Pensa-se o fotógrafo como aquele que precisa estar atento, aquele que tem um excelente desempenho diante de uma série de surpresas. Barthes lista cinco delas: a do "raro", a do "gesto apreendido no seu ponto de trajeto em que o olho normal não pode imobilizá-lo", a da "proeza", a das "contorções da técnica" e a do "achado". Esse poeta-operator estaria atento a, pelo menos, três ou quatro surpresas listadas por Barthes. Enfim, ele seria "como um acrobata", que "deve desafiar as leis do provável ou mesmo do possível; em última instância deve desafiar as do interesse" 54 . Essas leis, do provável e do interesse, se potencializam pelo procedimento solicitado por Manoel de Barros no poema: fora poema e poeta ("Nuvem de calça" e Maiakovski), fotografam-se, em sua maioria, coisas "invisíveis": silêncio, perfume, existência, perdão e sobre. E o desafio a essas leis parece compensatório, uma vez que "A foto saiu legal". Pode-se imaginar que há, não só um elogio, como um autoelogio da destreza do fotógrafo e isso sugere um projeto do alto modernismo, a revelação de "um modo genuinamente novo de ver (preciso, inteligente e até científico)" 55 , nada democrático, que faz do operator um gênio original. Isso, porém, não condiz com a prática poética de Barros, pois se há uma estranheza em sua "gramática" ela é, ao mesmo tempo, exposta aos leitores de maneira quase didática em muitos dos poemas ${ }^{56}$. Além disso, a presença de Maiakovski e do informalismo na hora de comentar o resultado da fotografia - "A foto saiu legal" - sugerem uma postura mais democrática e nada genial em cena.

É possível compreender esse poema, de modo mais instigante e produtivo, como o aprendizado de uma prática da experiência do olhar. Em diálogo com $A$ câmara clara, e sua
54. BARTHES, Roland. $A$ câmera clara, 2015, p. 34-35.

55. SONTAG, Sontag. Sobre fotografia. 2004, p. 115.

56. "Despalavra" e

"Comportamento" são dois exemplos disso em Ensaios fotográficos. Barros, Manoel de. Ensaios fotográficos, 2013, p. 21, p. 61-2. 
57. BAUDELAIRE, Charles. "O estrangeiro", 1976, p. 19.

58. MAIAKOVSKI, Vladimir. Poemas, 2003.

59. VERTOV, Dizga. "Nascimento do cine-olho (1924)", 2008, p. 262.

60. Idem. "Extrato do ABC dos Kinoks (1929)", 2008, p. 264. "ciência do sujeito" observador, não seria um contrassenso dizer que aquilo que é fotografado no poema é o punctum de cada uma das cenas, aquilo que não tem nome, como no studium, e que assim pode ferir quem observa a fotografia. Uma pergunta é colocada: como fotografar o punctum, se ele é uma instância crítica do observador, do spectator, que salta da fotografia depois dela revelada. Por um lado, pode-se afirmar que aquilo que o fotógrafo de Barros faz é desprogramar o olhar, escapar do "código civilizado das ilusões perfeitas", voltar a ser selvagem ou indomável. Pode-se dizer, inclusive, voltar a ser estrangeiro diante das imagens. A nuvem de Maiakovski me faz lembrar outra nuvem, essa incontinência visual, aquela que o "estrangeiro" de Charles Baudelaire ama. Depois de rejeitar/negar família, amigos, pátria, beleza e ouro, o "excêntrico estrangeiro" afirma seu amor: "Amo as nuvens... as nuvens que passam... longe... lá muito longe... as maravilhosas nuvens!" ${ }^{\prime 57}$. Nesse sentido, é estrangeiro aquele que ama a experiência de olhar aquilo que é incontinência e que, assim, não constituiu nenhum "código civilizado". Mas a desprogramação do olhar é uma prática e como prática estética requer um procedimento, talvez apresentado no poema de Barros.

É outra vez a presença de Maiakovski que sugere o entendimento da prática estética da desprogramação do olhar. É recorrente em Maiakovski um procedimento de aproximação de palavras de campos semânticos distintos, formando, assim, palavras compostas e expressões desconcertantes: "riso-espinho", "flauta-vértebra", "micro-futuristas", "pescoços-campanários", "coração-caverna”, "chuva lúgubre", "lampião calvo", "noturno louco", "flauta dos esgotos", entre muitas outras combinações ${ }^{58}$. Esse procedimento, inscrito na vanguarda construtivista russa, é próximo da montagem cinematográfica de certo cinema russo, sobretudo, da prática de montagem de Dziga Vertov e de seu "cine-olho". Este seria, segundo um dos manifestos do cineasta, a "possibilidade de tornar visível o invisível" 59 , de mostrar aquilo que o olho - sem o auxílio da câmera - não vê. Não só isso, mas o "cine-olho" é a montagem que já acontece "quando escolho um tema (ao escolher um dentre os milhares de temas possíveis") e "quando faço observações para o meu tema (realizar a escolha útil dentre as mil observações sobre o tema)", lê-se em outro manifesto ${ }^{60}$. Espécie de pré-montagem, esses procedimentos, anteriores à filmagem e montagem em si, parecem sugerir a prática de olhar as coisas, "invisíveis", do poeta-fotógrafo de Barros. Como se fosse possível, antes mesmo de tirar a fotografia, imaginar o resultado: antes de preparar sua "máquina", o operator já tinha visto o "silêncio" "carregando o bêbado". Na verdade, pode-se afirmar que há nesse fotógrafo uma prática de montagem do olhar, sem mesa de edição, que vê um "azul-perdão" no "olho de um mendigo" para depois fotografar o "perdão". Aquilo então que se parece com acaso, 
ou mágica, é, na verdade, uma experiência possível pela técnica, pela "máquina". Enfim, a desprogramação do olhar civilizado - da cultura e do capital - é aprendida com a máquina, na conjunção do olho com a objetiva, e apresentada através de palavras.

Não seria incorreto, por outro lado, pensar que o fotógrafo do poema seja um observador de fotografias, um spectator, ou um leitor de cenas (o fotógrafo é um leitor no poema, no caso da "Nuvem de calças"), que, se entregando, conta aquilo que o fere em cada uma das cenas. Tudo o que é visto, e depois fotografado, é invisível, e "invisível", segundo John Berger, é o "verdadeiro conteúdo de uma fotografia". Parece que Manoel de Barros, ao escrever o poema, solicite um modo de ver o mundo como o dos fotógrafos, atravessado pela técnica e pela possibilidade de ver o invisível animar a imagem. E se há alguma mágica nisso, ela é resultado da técnica e não de um misticismo natural, e romântico, que atribuem a sua poética - as coisas invisíveis saem, fantasmaticamente, das cenas com o auxílio da câmera. É o "despertar da intratável realidade", na expressão de Barthes, que é revelada pelo fotógrafo ao sair de "uma festa", "quase quatro da manhã". Intratável realidade daquilo que desaba sobre uma casa, do perdão de um "mendigo", da existência de um pequeno molusco e da morte de um poeta russo. "Agora se pode fotografar tudo", sobretudo, a "dissolução implacável do tempo" - na expressão de Sontag - e a nossa morte, invisível ainda, mas presente naquilo que desaba, no perdão de alguém, na menor das existências e na morte do outro, mesmo que só tenha visto o outro em uma fotografia que "saiu legal". 


\section{Referências}

ALMEIDA, Bernardo Pinto de. Imagem da fotografia. Lisboa:

Relógio D’água, 2013.

BARROS, Manoel de. Ensaios fotográficos. In: Biblioteca

Manoel de Barros [coleção]. São Paulo: LeYa, 2013.

BARTHES, Roland. Aula. São Paulo: Cultrix, 1995.

. "Brecht e o discurso: contribuição para o estudo da discursividade". In: . O rumor da língua. São Paulo:

Martins Fontes, 2004, p. 269-281.

- A câmara clara: nota sobre a fotografia [ed. especial]. Rio de Janeiro: Nova Fronteira, 2015.

BAUDELAIRE, Charles. "O estrangeiro". In:

Pequenos poemas em prosa. Rio de Janeiro: Nova Fronteira, p. 19.

BENJAMIN, Walter. "Pequena história da fotografia". In: - Magia e técnica, arte e política: ensaios sobre literatura e

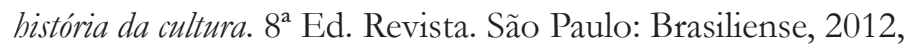
p. 97-115.

. "O narrador: considerações sobre a obra de Nikolai

Leskov". In: - Magia e técnica, arte e política: ensaios sobre literatura e história da cultura. $8^{\mathrm{a}}$ Ed. Revista. São Paulo: Brasiliense, 2012, p. 213-240.

BERGER, John. "Compreender uma fotografia". In: TRACHTENBERG, Alan. Ensaios sobre fotografia: de Niépce a Krauss. Lisboa: Orfeu Negro, 2013, p. 317-320.

FRANK, Robert. The americans. Göttingen: Steidl, 2008.

KEROUAC, Jack. "Introduction". In: FRANK, Robert. The americans. Göttingen: Steidl, 2008, s/p.

LINN, Judy. Patti Smith 1969-1976. New York: Abrams, 2011.

MAIAKOVSKI, Vladimir. Poemas. $7^{\text {a }}$ Edição. São Paulo:

Perspectiva, 2003.

POE, Edgar Allan. "O daguerreotipo”. In:

TRACHTENBERG, Alan. Ensaios sobre fotografia: de Niépce a Krauss. Lisboa: Orfeu Negro, 2013, p.55-56.

SMITH, Patti. Só garotos. São Paulo: Companhia das Letras, 2010.

SONTAG, Susan. Sobre fotografia. São Paulo: Companhia das Letras, 2004. 
VERTOV, Dziga. "Nascimento do cine-olho (1924)". In:

XAVIER, Ismail (Org.). A experiência do cinema. São Paulo:

Edições Graal, 2008, p. 206-262.

"Extrato do ABC dos Kinoks (1929)". In: XAVIER,

Ismail (Org.). A experiência do cinema. São Paulo: Edições Graal, 2008, p. 263-266. 
